\title{
RAISED SERUM LDL IN CHRONIC EXCESS ALCOHOLISM AS A RISK FACTOR FOR STROKE
}

\author{
Chelladurai Kandaswamy1, Panimathi Rengaramanujam²
}

${ }_{1}^{1}$ Associate Professor, Department of Biochemistry, Madras Medical College, Chennai, Tamilnadu, India.

2Professor, Department of Biochemistry, Madras Medical College, Chennai, Tamilnadu, India.

\section{BACKGROUND}

ABSTRACT

As far as ischaemic stroke is concerned, prevention is only facilitated by an understanding of predisposing host, risk and environmental factors. WHO defines stroke as rapidly developed clinical signs of focal or global disturbance of cerebral functions lasting more than 24 hours or leading to death with no apparent cause other than vascular origin. The 24 hours "definition" excludes transient ischaemic attack (TIA). Cerebral thrombosis is usually the most frequent form of stroke encountered in clinical studies followed by haemorrhage. We wanted to analyse serum LDL, AST and ALT concentration in chronic excess alcoholism with stroke and to study the relation between LDL and stroke.

\section{METHODS}

This is a comparative cross-sectional study. The study population consists of two groups; group one consists of 50 persons with self-reported, regular, excess, chronic alcohol intake (greater than $400 \mathrm{~g}$ per week which approximately equal to $1400 \mathrm{ml}$ per week or $200 \mathrm{ml}$ per day); group two consists of patients with stroke who take alcohol similarly. Serum LDL was analysed, and statistical analysis made in relation to both the groups.

\section{RESULTS}

The mean values of serum LDL were significantly elevated in cases compared to controls with a p value at 0.021 .

\section{CONCLUSIONS}

LDL which is the biological marker of atherosclerosis can be used to assess the risk of stroke especially in chronic excess alcoholism. Excessive drinking of alcohol with increased LDL-cholesterol compounds the risk for stroke.

HOW TO CITE THIS ARTICLE: Kandaswamy C, Rengaramanujam P. Raised serum LDL in chronic excess alcoholism as a risk factor for stroke. J. Evolution Med. Dent. Sci. 2019;8(13):1036-1038, DOI: 10.14260/jemds/2019/229

\section{BACKGROUND}

Stroke results in enormous costs measured in both healthcare expenses and lost productivity ${ }^{1}$ which is vital for a nation especially India where 12 per cent of stroke cases are below 40 years of age ${ }^{2}$ with a total prevalence of $8.5 .^{3}$

Low density lipoprotein is the major carrier of cholesterol in blood. It contains a core of about 1500 cholesterol molecules esterified to fatty acids. The most common fatty acid chain in these esters is linoleate-a polyunsaturated fatty acid. A shell of phospholipids, about 500 molecules of nonesterified cholesterol surrounds this highly hydrophobic core. The shell also contains a single copy of apo-protein B100 (One of the single largest polypeptide chains known with 4536 amino acids) which is recognized by the target cells. The role of LDL is to deliver cholesterol to peripheral tissues and regulate de novo cholesterol synthesis in these tissues.

In circulation during the hydrolysis of VLDL by lipoprotein lipase (LPL) the $C$ apoprotein are transferred to HDL and VLDL is converted to VLDL remnants. The remnants are taken by the liver through E receptors and hepatic lipase hydrolysis it and remove the remaining TGs and converted it into smaller IDL particles.

'Financial or Other Competing Interest': None.

Submission 04-03-2019, Peer Review 25-03-2019,

Acceptance 27-03-2019, Published 01-04-2019.

Corresponding Author:

Dr. Panimathi Rengaramanujam,

Professor, Department of Biochemistry,

Madras Medical College, Chennai,

Tamilnadu, India.

E-mail: panimathi@hotmail.com

DOI: $10.14260 /$ jemds $/ 2019 / 229$
The cholesterol ester transfer proteins (CETP) transfer cholesterol to HDL in exchange of phospholipids free cholesterol and apolipoprotein. The net result of coupled hydrolysis and the cholesterol exchange reactions is the replacement of much of the TG core of original VLDL with cholesterol esters. This process ends with ultimate formation of LDL with own apoprotein B100 intact. Thus, each LDL is derived from a single precursor VLDL particle. 4

In humans a relatively large proportion of IDL forms LDL, accounting for the increased concentration of LDL compared to many other mammals. ${ }^{5}$

Alcoholism has been defined as the repeated ingestion of alcohol resulting in dependency, disease or harm.

Dependency: It is characterized by drink orientated behaviour, tolerance to the cerebral effects of alcohol, continued drinking despite harm and withdrawal symptoms with abstinence. Excess alcohol consumption: It may be considered as regular alcohol intake at levels at which there is a high risk of harm particularly from organ injury.

Where such intake is accompanied by actual harm the terms 'harmful drinking' or 'alcoholism' may be used (Syn. alcohol abuse). A plasma level of ethanol between 250 to 300 $\mathrm{mg}$ per $100 \mathrm{ml}$ is termed intoxication. There is a high risk of harm from alcohol intake greater than 400 g per week ${ }^{6}$ which approximately equal to $1400 \mathrm{ml}$ of brandy or just $200 \mathrm{ml}$ per day. This approximation holds good for a genuine brand and if the drink is adulterated there is still more danger. If it is a country-made liquor or arrack the chances of consumption of pure ethanol is actually more. These two are the common 'drinks' consumed in our country.

By pharmacological definition alcohol is a drug and may be classified as a sedative, tranquilizer, hypnotic or anaesthetic depending upon the quantity consumed. Off all 
the drug alcohol is the only drug whose self-intoxication is socially acceptable. Over the past years increasing percentages of young people have started to drink alcoholic beverages and their alcohol consumption has increased in quantity and frequency and the age at which drinking starts has declined. This situation is disturbing because the young people concerned may run a greater risk of alcoholic problem in later life and also in the short term, increased involvement in road accidents.

According to current concept alcoholism is considered a disease and alcohol - a disease agent. The health problem for which alcohol is responsible is only part of the total social damage it causes. ${ }^{7} \mathrm{~A}$ national survey found that the about $31.9 \%$ of men and $2.2 \%$ of women drink alcohol and about 9.9\% of men drink alcohol every day in India. The overall prevalence in our state is about $40 \%$ and these surveys had been taken during 2005-06.8 however with one TASMAC shop at each main road the prevalence would even be bigger than we expect.

\section{Abnormalities of AST (Aspartate Amino Transferase), ALT (Alanine Amino Transferase)}

An AST: ALT ratio of more than 2 suggests alcoholism. ${ }^{9}$ However pyridoxine deficiency which is common in chronic alcoholics, alter the pattern of ratio as the ALT is more dependent upon pyridoxine rather than AST.10

\section{METHODS}

This is an age and sex matched comparative cross-sectional study. The study population includes two groups; group 1 (control) consists of 50, self- reported, chronic, regular and excess alcohol drinking persons; group 2 (cases) consists of stroke patients who have been taking alcohol similarly. The cases who were confirmed by clinical and MRI have been selected. The alcohol content is of the drink taken into account than the type of drink. Irrespective age cases and controls selected based upon their drinking habit and amount-drinking with more than $400 \mathrm{mg}$ per week (around $200 \mathrm{ml}$ per day or $1200 \mathrm{ml}$ per week); brandy being the commonest 'drink' in our set up.

Patients with liver disease; who are taking drugs like phenytoin, barbiturate, oestrogen-containing contraceptives, rifampicin; and those who are not willing are excluded from the study

The study was presented before the Ethical Committee of Stanley Medical College and formal approval was obtained.

\section{Sample Collection and Analysis}

Random venous blood sample of $5 \mathrm{ml}$ was collected; the sample centrifuged; serum separated and analysed for the following-

1. Low-Density Lipoproteins (LDL)

2. Aspartate Aminotransferase (AST)

3. Alanine Aminotransferase (ALT)

NB: The AST and ALT were analysed for the purpose of ratio in chronic alcoholism.

\section{RESULTS}

Total cases 50; controls 50 were selected on the basis of availability of stroke patients (Ischaemic type) during a particular period of time. Hence only a small number of subjects were selected with a possibility of scope to study it later with larger population groups in future.

\begin{tabular}{|c|c|c|c|c|c|c|}
\hline Age & Test & Group & $\mathbf{N}$ & Mean & SD & p Value \\
\hline $31-40$ & & $\begin{array}{c}\text { Control } \\
\text { Cases }\end{array}$ & $\begin{array}{l}3 \\
3\end{array}$ & $\begin{array}{l}51.00 \\
59.33\end{array}$ & $\begin{array}{l}7.000 \\
9.504 \\
\end{array}$ & 0.289 \\
\hline $40-50$ & & $\begin{array}{c}\text { Control } \\
\text { Cases }\end{array}$ & $\begin{array}{l}17 \\
17\end{array}$ & $\begin{array}{l}75.88 \\
92.35 \\
\end{array}$ & $\begin{array}{l}33.134 \\
43.000\end{array}$ & 0.222 \\
\hline $50-60$ & LDL & $\begin{array}{c}\text { Control } \\
\text { Cases }\end{array}$ & $\begin{array}{l}22 \\
22 \\
\end{array}$ & $\begin{array}{c}85.23 \\
101.73 \\
\end{array}$ & $\begin{array}{l}28.382 \\
33.675 \\
\end{array}$ & 0.046 \\
\hline $60-70$ & & $\begin{array}{c}\text { Control } \\
\text { Cases }\end{array}$ & $\begin{array}{l}7 \\
7 \\
\end{array}$ & $\begin{array}{c}92.57 \\
101.00 \\
\end{array}$ & $\begin{array}{l}27.122 \\
28.787 \\
\end{array}$ & 0.593 \\
\hline $\begin{array}{c}\text { More } \\
\text { than } 70\end{array}$ & & $\begin{array}{c}\text { Control } \\
\text { Cases } \\
\end{array}$ & $\begin{array}{l}1 \\
1 \\
\end{array}$ & $\begin{array}{l}103 \\
170 \\
\end{array}$ & & \\
\hline
\end{tabular}

\section{Statistics}

This student's ' $t$ ' tests were used to find out the test of significance, the $\mathrm{p}$ value, of both cases and controls in each group and are shown in table 1 and 2 .

\begin{tabular}{|c|c|c|c|}
\hline Variable & Study Group & Control Group & p Value \\
\hline LDL & $\begin{array}{c}\text { Mean } 97.26 \\
\text { SD } 37.55\end{array}$ & $\begin{array}{c}\text { Mean } 81.38 \\
\text { SD } 29.94\end{array}$ & 0.021 \\
\hline \multicolumn{4}{|c|}{ Table 2 } \\
\hline
\end{tabular}

\section{DISCUSSION}

In patients with stroke though we say the desirable level of LDL less is than $130 \mathrm{mg}$ per $\mathrm{dl}$, those people with risk category the desirable is less than $100 \mathrm{mg}$ per $\mathrm{dl}$ is well exemplified that in the age group 50-60; 60-70 and beyond 70 where the minimum was $101 \mathrm{mg}$ and maximum was 170 mg per dl. It's the amount of alcohol, long duration of drinking (Starting of drinking happens at an early age which is worry-some in our country) that has to be taken into consideration in this age group. But this aspect is strongly associated with age group less than 50 . All these aspects need further study with larger population group, as in our country about 32 per cent of men and nearly 3 per cent of women drink alcohol. The corresponding figure in our state is about 42 and 0.1 in our state respectively as we already seen.

Current guidelines of the American Heart Association and proposed modifications of the NCEP-III guidelines would therefore suggest that all patients at risk for stroke or who have had a cerebral infarction should be treated to a goal LDL level of below $70 \mathrm{mg} / \mathrm{dl}^{11}$ The intervention trials like MRFIT (Multiple Risk Factor Intervention Trial) showed high cholesterol level to be associated with increased mortality and morbidity due to atherosclerosis. ${ }^{12}$ and there by advocating to reduce LDL cholesterol with use of statins. Togha et al observed that the risk of developing ischemic stroke increases as the total cholesterol and LDL values rise. If other risk factors like smoking, diabetes, hypertension, obesity are there, the incidence of stroke particularly ischaemic type is definitely more.

\section{CONCLUSIONS}

This study supports the hypothesis that excessive and chronic alcohol consumption with raised LDL cholesterol level compounds the risk of stroke. A better understanding of the risk factors would be ideal for the primary prevention of stroke which is so essential as always in the control of noncommunicable diseases. 


\section{REFERENCES}

[1] Sacco RL. Pathogenesis, classification and epidemiology of cerebrovascular diseases. In: Rowland LP, edr. Merritt's Neurology. 10th edn. Philadelphia: Lippincott Williams and Wilkins 2000: p. $217,226 \& 227$.

[2] Anand K, Chowdhury D, Sing KB, et al. Estimation of mortality and morbidity due to strokes in India. J Neuroepidemiology 2001;20(3):208-11.

[3] Indrayan A. Forecasting vascular diseases and associated mortality in India, Burden of Disease in India, National Commossion on Macro-economics and Health Background Papers, Ministry of Health and Family Welfare, Govt. of India, New Delhi, Bulletin, Sep 2005: p. 205.

[4] Rifai N, Warnick RG. Lipoprotein metabolism. In: Burtis CA, Ashwood ER, David E Bruns DE, eds. Tietz Textbook of Clinical chemistry and molecular diagnostics. $4^{\text {th }}$ edn. Saunders 2006: p. 917-9.

[5] Botham KM, Mayes PA. Lipid transport and storage. In: Murray RK, Granner DK, Rodwell WW, eds. Harper's Illustrated Biochemistry. 27th edn. McGraw-Hill Publication 2006: p. 220-1.

[6] Rosalki SB. Clinical biochemistry of alcohol. In: Williams DL, Marks V, eds. Scientific foundations of biochemistry in clinical practice. $2^{\text {nd }}$ edn. Butterworth Heinemann 1994: p. 121, 128 \& 129.
[7] Park K. Stroke. In: Park K, edr. Parks Textbook of Social and preventive medicine. $16^{\text {th }}$ edn. M/s Banarsidas Bhanot Publisher 2000: p. 280-1.

[8] Morbidity and Health Care, Section 13, National Family Health Survey 3, Vol. I., Ministry of Health and Family Welfare, Govt. of India, 2005-06, International Institute of Population Sciences and Macro International 2007: p. 429-31.

[9] Johnson PJ. Acute and chronic liver diseases. In: Marshall WJ, Bangert SK, eds. Clinical chemistry, metabolic and molecular aspects. $4^{\text {th }}$ edn. Churchill Livingstone 2000: p. 243-4.

[10] Halsted CH. Water soluble vitamins. In: Garrow JS, James WPT, Ralph A, eds. Human nutrition and dietetics. 9th edn. Churchill Livingstone 1993: p. 254.

[11] Expert Panel on Detection, Evaluation and Treatment of High Blood Cholesterol in Adults. Executive Summary of the Third Report of the National Cholesterol Education Program (NCEP) (Adult Treatment Panel III). JAMA 2001;285(19):2486-97.

[12] Iso H, Jacobs DR Jr, Wentworth D, et al. MRFIT Research Group. Serum cholesterol levels and six year mortality from stroke in 350, 977 men screened for the multiple risk factor intervention trial. N Engl J Med 1989;320(14):904-10. 